\title{
Deconstructing the Ethnos - Nation Distinction
}

\author{
Marianna Papastephanou ${ }^{1}$ \\ ${ }^{1}$ Department of Education, University of Cyprus, Nicosia, Cyprus \\ Correspondence: Marianna Papastephanou, Department of Education, University of Cyprus, PO Box 20537, \\ Nicosia 1678, Cyprus. Tel: 3-572-249-8683. E-mail: edmari@ucy.ac.cy
}

Received: October 1, 2012 Accepted: October 25, 2012 Online Published: November 29, 2012

doi:10.5539/jpl.v5n4p147 URL: http://dx.doi.org/10.5539/jpl.v5n4p147

\begin{abstract}
Two major theoretical tendencies are noticeable in discussions of the ethnos and the nation. The one identifies them and uses them alternatively and in a largely de-politicized sense. The other sets them in drastic opposition, associating the ethnos with apolitical collective affect based on biology or culture and the nation with contractuality and statehood. This article steers clear from both tendencies and argues for a re-conceptualization of ethnos along lines that stem from its etymology and the post-metaphysical possibilities it carries. To this end, an argument is expounded about why the limited translatability of ethnos into nation, the surplus of semantic possibilities of the former that cannot be totally channeled into the latter, opens a path toward a more convincing and inclusive conception of patriotism. The full-fledged patriotism thus promoted accommodates the ethnic element in modes that are, hopefully, compatible with, and even conducive to, cosmopolitanism.
\end{abstract}

Keywords: patriotism, cosmopolitanism, communitarianism, Habermas, Fanon, justice, anti-nationalism

\section{Introduction}

Ethnic belonging is typically construed as allegiance to a specific collectivity in virtue of descent and/or culture regardless of whether this collectivity is also a political configuration or not. Ethnic belonging is often coupled with an ethnic sense of patriotism (Kleingeld, 2000) or with 'ethnic nationalism' (Nairn, 1998, p. 123), depending on the semantic content of the patria and the nation of the corresponding -isms (patriotism, nationalism) (Seriot, 1997; Smith, 2000; Anderson, 2002; Kaldor, 2004; Calhoun, 2007). Specific political conclusions are then derived from ethnic allegiance; for instance, the ethnic is taken to be the pre-modern core, the 'navel' (Hall, 1998, p. 6) that sustained the reality (Hroch, 1998), or the myth (Gellner, 2004), or the imaginary unity (Anderson, 2002) of the nation-state in modernity. Yet, the bond among ethnic consociates is not viewed as inherently political but rather as biological or cultural.

The de-politicization effected by the association of the ethnic with the biological has contributed to the former's falling into disrepute. As A. D. Smith puts it, for scholars, 'the ethnic version [of nationalism] remains profoundly suspect. It is widely equated with the exclusiveness of "blood" associated with the organic version of nationalism" (2000, p. 16). This suspicion is no wonder, given all the negative historical record of collective, exclusivist and discriminatory perceptions of ethnic alterity on grounds of bloodline. Confronting the ongoing tendency to identify kinship as a basis of national affect adherents to nationalism try to salvage it by jettisoning the ethnic predicate and by couching nationalism in purely modern, governmental idioms.

This results in a dichotomous differentiation and tension between ethnos and nation, where the former is seen as reflecting an obsolete and dangerous affect on grounds of consanguinity and the latter is seen as reflecting a resilient, modern version of affect on grounds of contractuality and political consensus. As we shall see later on, an opposite tendency treats the ethnos and the nation as synonyms (both signifying common descent) and uses them alternatively. It does so either to dismiss them both or to proclaim them the inescapable sentimental basis of any liberal political formation. Despite their differences, both tendencies, i.e. the one that treats ethnos - nation as a binary opposition and the other that identifies ethnos - nation, leave the paradigmatic assumptions about the ethnos being as such apolitical and relying on kinship and/or culture unaltered.

This article aims to challenge the paradigmatic assumptions of the above tendencies. It maps them first and then moves to a critical discussion of their conception of ethnos. It re-conceptualizes the ethnic against its wrongheaded identification with bloodline or with a de-politicized notion of culture. To redeem a 'non-toxic' ethnic possibility and to break with its jaundiced disparagement, the article employs the ethnos - nation distinction in ways that have 
not been followed in the relevant literature. A critique of J. Habermas's use of the terms 'ethnos' and 'nation' interchangeably offers the springboard for showing the limited translatability of ethnos into nation. Such translatability is limited for a very subversive reason: rather than the ethnos being biologically determined and the nation politically determined, etymologically-conceptually, it is the other way round. Moreover, there is a surplus of semantic possibilities of ethnos that cannot be totally channeled into the nation. This surplus may open a path toward a more convincing, inclusive and post-metaphysical conception of patriotism/nationalism. This path has, to my knowledge, been hitherto unexplored, but it can prove to be henceforth fertile for articulating the possibility of a positive account of the ethnic affect, of its complex relation to culture and politics and of its compatibility with cosmopolitanism.

If that is the case, then ethnos matters, not only in the historical and socio-political sense of being, qua ethnicity/ethnie, the root of a phenomenon such as the nation-state (and the nation underpinning it) which has not yet eclipsed and may not eclipse in the foreseeable future. Ethnos matters also in the normative sense of a category that can be acknowledged in ways not only permissible but even conducive to justice.

\section{The Main Tendencies of Theorizing the Relation of Ethnos and Nation}

Let us begin with the tendency to conflate ethnos and nation, as it is simpler to describe. In fact, within such a tendency it may not be correct even to talk about a relation of ethnos and nation because a relation presupposes the distinctiveness of the terms in question. It is more accurate to talk about a confounding identification of the two. This identification presupposes an easy and unproblematic translatability of ethnos into nation, fails to offer a nuanced account of these two terms, and uses them interchangeably. Here is an example of identification: 'in original Greek usage ethnos refers to nation' (Nederveen Pieterse, 1996, p. 25). Now, when the nation is defined in terms of extended family and becomes de-politicized, the term patria is recruited to cover the terminological space of the political conception of love of a country. Here is how patria is differentiated from nation in Karl Deutsch's outlook: patriotism refers to patria as a country and nationalism to a Natio as, literally, a group of common descent and upbringing (cf Viroli, 2003, p. 3). Likewise, for the conservative theorist R. Scruton, the political idea of the liberal state 'depends, and ought to depend, upon a non-political idea of membership' (Scruton, 2003, p. 273). The latter corresponds to the nation.

In fact, Scruton maintains a de-politicized notion of the national bond (p. 283), but he limits its relation to kinship or to homogeneous genetics as much as possible by subjectifying it. Members of a national group identify themselves in terms of a common descent' (Scruton, 2003, p. 274); therefore, common descent is not so much an objective reality but rather a self-conception or an imaginary projection. Nevertheless, such identification with descent is, for Scruton, a 'feature of the pre-political unity' of nationals 'which cannot be discarded without detriment to [the nation's] cohesion' (ibid). Despite differences from Scruton's views, D. Miller's account of ethnic belonging also concurs in arguing that membership in ethnic identity 'can only be acquired by birth. Although a priori a nation might define itself tightly by descent, in practice nations extend membership more or less freely to those who are resident' (Miller, 2003, p. 311). The cultural element is also accommodated within this framework. The national group is not necessarily 'constituted by biological descent. The common traits can be cultural in character: they can consist in shared values, shared tastes or sensibilities' (Miller, 2003, p. 307).

From another perspective, a communitarian one that is redolent of structural-functionalist leanings (Taylor, 1998, pp. 192-6), patriotism is the collective ethos that secures allegiance to democratic practices and concessions of privileges for the sake of common benefit (Taylor, 1996). For 'democracies require a relatively strong commitment on the part of their citizens' (Taylor, 1998, p. 200); 'in other words, the modern democratic state needs a healthy degree of what used to be called patriotism, a strong sense of identification with the polity, and a willingness to give of oneself for its sake' (ibid, p. 201). More generally, in most approaches nowadays, the tendency is to use the term 'national/ethnic patriotism' to denote the focus on the national/ethnic group to which one belongs, and not the focus on the political commonwealth in which one is a citizen (Kleingeld, 2000, p. 319; Taylor, 1998, p. 201). The ethnic is thus de-politicized and considered cultural or biological. True, there is an ambiguity in the employment of the term 'nation' to refer to descent and heritage as well as to political self-assertion. Thus, the nation is de-politicized in some cases too. We may notice even country-relative conceptions of the nation in relation to the nation-state (Seriot, 1997, p. 42). However, both ethnos and nation appear sometimes re-politicized, which means that the ambiguity is common to the usage of 'ethnos' and not just of 'nation', but it is more often encountered in the usage of 'nation', as the 'ethnos' is more sweepingly and frequently de-politicized in a unambiguous way than the nation.

As for the familial element that is typically associated with consanguinity, it is employed by many proponents of nationalism (who politicize the nation and confine bloodline to ethnicity) for metaphorical purposes. Ironically, 
whereas the familial is ousted from the literal plane of accounting for the bond itself, it is functional at the figurative plane when theorists wish to draw analogies between operations of a family and operations of a national political configuration. Such is, for instance, the use Alasdair MacIntyre makes of the familial metaphor when he claims that reciprocal self-interest is as insufficient in the case of a nation to explain its bond as it would be in the case of a family (MacIntyre, 2003, p. 298) (Note 1). Likewise, Miller employs an analogy with the family in order to clarify a point about national obligations being independent from one's feelings for particular persons-members of the nation (Miller, 2003, p. 315) (Note 2). In a way, the political operations of the nation seem to become a form of the functional, 'managerial' operations of the family, the oikos in ancient [and Arendtian (1989)] terms, as the connotations of familial metaphors are unwittingly carried along in such parallelisms.

Now, on the other side of the political geography, that is, beyond some versions of liberalism and communitarianism, we encounter a wholesale incrimination of the nation and a downright rejection of nationalism. Within that framework, as C. Calhoun criticizes it, nationalism is often treated 'as a sort of error smart people will readily move beyond - or an evil good people must reject' (Calhoun, 2007, p. 7). B. Anderson also comments disapprovingly on being 'common for progressive, cosmopolitan intellectuals' to insist on 'the near-pathological character of nationalism' (Anderson, 2002, p. 141). The disparagement of national affect forces many theorists of patriotism to take what they see as an appropriate distance from the kindred worldview of nationalism. Thus, although there are still proponents of patriotism who take it to 'consist in loyalty to a particular nation', very many think of patriotism as 'the love of political liberty and the institutions that sustain it, or a matter of self-conception and identity' (Kleingeld, 2000, p. 316) (Note 3). Still, they do not escape attacks from other circles, for instance, some liberal and Marxist ones, whose well-known hostility to patriotism extends even to conceptions of it as a political virtue (O' Leary, 1998, p. 41). For sure, there are also other standpoints combining the above positions and giving the terms 'patriotism' and 'nationalism' an ambiguous or even protean and elastic character, but, arguably, an observational conclusion from any glance at the relevant literature is that the tendency to de-nationalize patriotism dominates.

Then again, the attack on any possible meaning of nationalism, national/ethnic patriotism), national consciousness and national identity (Note 4) has itself undergone changes. But those changes have blocked a more nuanced thinking. The polemics that such changes have consolidated preserve conceptual confusions, sweeping generalizations and blanket incriminations of national feeling (Brennan, 1989, p. 2) on ever shifting grounds (e.g. nationalism is now considered by many not so much pernicious as outdated). They have not led to re-conceptualizations or to a deeper questioning of the ontologization (Note 5) of modern semantic contents of the involved terms. That nationalism is largely viewed as a moral mistake (Calhoun, 2007) has not led to any problematization of the paradigmatic assumptions about the meaning of ethnos and nation and their relation. These have remained unaltered, as the difference between the proponents and opponents of nationalism concerns qualitative rather than conceptual stakes. When identified, the nation and the ethnos typically become de-politicized. When rigidly demarcated, they are set in a bipolar relation where nation signifies contractual partnership among consociates and ethnos signifies unchosen communal bond. The latter is based on non-negotiable ties of membership (kinship or a determinist notion of socio-cultural conditioning) and/or bound by Schicksal and other such metaphysical notions.

It is true that 'the opposition of civic and ethnic nationalisms exerts a powerful influence over the study of nationalism', but, as Calhoun remarks, 'like many typologies it obscures as much as it reveals' (Calhoun, 2007, p. 146). Some theorists have questioned the 'civic/ethnic nationalism' dichotomy, especially in its simplistic form (Brubaker, 1998, pp. 298-301), but this has not been the case for the 'ethnos versus nation' dichotomy or for the hasty identification of the two terms. The ethnic is considered harmless only when de-politicized; it appears that deep down the fear is that, if the ethnic acquires political significance, totalitarianism, discrimination and exclusion will cross our threshold. Now, are the risks of sliding into undesirable and pernicious doubles exclusive to ethnic/national attachment? If yes, then, one might say that the de-politicization of the ethnic variation of collective sentiment is justified. If no, then there is no compelling argument in favor of a blanket indictment of the ethnic politicization. I argue elsewhere (Papastephanou, n.d) that there is no compelling argument, deriving from the fear of degeneration, in favor of neglecting, say, ethnic patriotism. Yet, that ethnic patriotism/nationalism (Note 6) is not the only kind that is prone to degeneration into dangerous doctrines does not quite entail that it is not expendable for other reasons. As mentioned above, civic patriotism/nationalism often dispenses with it because it sees in its supposedly inherent connection to kinship (and/or to a folklore sense of culture) an inappropriate source of political legitimacy or a force that is totally irrelevant to politics. Is that, indeed, the case? 


\section{Constitutional Patriotism and its De-politicization of Ethnos}

Let us elaborate on this through a critical outlook on J. Habermas's version of patriotism (Habermas, 1996b). Habermas's notion of a constitutional patriotism becomes extremely relevant for the politics of multiethnic states or regionalist quasi-federations. It avoids the emphasis on performativity that lurks in functionalist, reproductive accounts of society. It also avoids the emotivist prioritization of a communal ethos grounded in a binding past, an ethos that is not always available and cannot be created by force. Instead, Habermas's constitutional patriotism opts for a purely legal-political commitment to common principles and political visions. Those can bind even communities whose past has been one of friction, conflict or even disproportionate violence of the one (conquering power) against the other (the conquered). For some such communities, separatism, parting of the ways, is no option for various plausible reasons. The stake they confront - whose typical under-theorization is a symptom that Sigal Ben-Porath (2006) has pertinently detected - is to make a fresh political start, to create a new, common political future. Ethnically (meaning here: affectively, historically and culturally) they may not share enough to have a commonality of the sort that used to bind older political configurations; and commonalities of that kind cannot be constructed artificially or in a short time. Perhaps the only or the best option such communities encounter is to create their own (positively meant) political utopia (i.e., to maintain their distinctive ethnic identities as lively, operative identities but to reconcile them with the state-political identity that is shaped by the common vision of peaceful togetherness and the common future of no apartheids). Constitutional patriotism means, then, that citizens will develop a patriotic stance toward a shared frame of political thought and action that will comprise all the maxims that would meet the agreement of all those affected by the constitution. With its formalist emphasis on debating principles and its proceduralist openness to futurity and to the unexpected, constitutional patriotism, or any legal-political patriotism more generally, can be a supplement and corrective to national/ethnic patriotism. It should not be treated as an enlarged substitute of nationalism that repeats the failures of nation-statism by operating in a similar way and by deriving its force from Realpolitik historical contingencies (producing badly-buried pasts and, hence, vampiric realities).

Although Habermas's constitutional patriotism merits welcome - even if qualified - one of the problems we may detect in it (one that is relevant to the aim of the article) is that it does not accommodate the positive political significance that ethnic affect can have. Constitutional patriotism fails to do so because it maintains the modern conception of the nation, if only to de-politicize it, relegate it to a semiprivate sphere and even (depending on relevant textuality) discard it. In this sense, it is emblematic of the more general theoretical tendency that we have already mentioned. Much like other critical theorists, e.g. D. Held (2003, p. 469), Habermas also sees the politicization of the nation as a discontinuous moment in modern history. On this, he is on a par with most contemporary scholarly orthodoxy: for instance, though Scruton generally shares too little with Habermas, he also sees the experience of national membership as 'precisely not political, but social' (Scruton, 2003, p. 278). In my view, this reflects a deeper, modern narrowing of the concept of the political, making it denote governance and a specific 'managerial', political ordering (Arendt, 1989, pp. 25-30), much against what the political used to signify in Greek antiquity (Arendt, 1989; Dawson, 1992). To explain, D. Dawson distinguishes between the political in the fullest Greek sense and the political in a common modern sense. The political in the Greek sense proposed that one dealt with the affairs of the polis, which did not necessarily 'include programs for immediate action', that is, with the politika in the sense of reforms of a public and social nature'. By contrast, the political in the modern sense recommends that one be 'engaged in or taking sides in the struggle for governmental power' (Dawson, 1992, p. 6).

Be that as it may, as Knight Abowitz and Harnish sum up Habermas' position, 'until the middle of the $18^{\text {th }}$ century, and later in many cases, nations were communities of people linked by heredity. "Hereditary nationality gave way to an acquired nationalism" after the French Revolution, and that form of nationalism "was able to foster people's identification with a role which demanded a high degree of personal commitment"' (Knight Abowitz and Harnish, 2006, p. 682, fn 6). Indeed, Habermas uses as a token of the apolitical and biologistic character of the nation the fact that "even Kant still maintained that "that group which recognizes itself as being gathered together in a society due to common descent shall be called a nation (gens)" (Habermas, 1996a, p. 22). Significantly, in the same text, Habermas omits any reference to the broader sense of the political involved in the affect that grounded ethnic claims, anti-colonial movements and insurrections related to the principle of self-determination as a principle of democracy in action.

Habermas generalizes the idea that until the 18th century nations were communities linked with heredity in an apolitical sense (Note 7). However, things had not been quite so, since there have been historical examples of conquered peoples claiming their freedom on grounds of ethnicity, territoriality and language. An example of the connection between resistance, irredentism, self-determination, land, nation and language is found as early as 968 AD in Liudprand's (bishop of Cremona) report of his mission to Constantinople where he confronted Nikēphorus 
(the Byzantine emperor) with the following words: 'the Land which you say belongs to your empire belongs, as the nationality and language of the people proves, to the kingdom of Italy' (emph mine) (Note 8). Neither this nor, for instance, the nationalist rhetoric in Shakespeare's plays, which causes unease to Gellner and others (Hall, 1998, p. 6) and which provides a favorite example to defenders of national realism such as Scruton (2003, p. 273), are sufficient empirical evidence for a claim as strong and all-encompassing as primordialism. But what the above case shows is that the political function of awareness of belonging and the connection with land is not limited to modernity. And, for this, numerous further examples can be drawn from antiquity to the present (at least from Greek antiquity and perhaps more broadly, although this should be subject to further empirical-historical research). It has to be said again, however, that the term 'political' is not used here in the narrow and flat sense of configuration, ordering and governance but in a broader sense of raising voice, claims, and confrontational words, contesting space, debating institutional power, and maintaining a revolutionary, ethical vision of collective life.

More generally, the identity corresponding to the collectivity 'nation' had, throughout history, at various times, been politically activated (though, surely, not always for the better but often for the worse). Besides, no identity is by definition divorced from political activation. Rather than being arbitrarily condemned to obsolescence or sweepingly demonized, national/ethnic identity, just as any of the multiple identities that make us up as human beings, can acquire political significance whenever there is contestation of space as resistance to domination and not just to power. For instance, one's identity as a woman may stand out and become politically operative when she feels and judges that women suffer (Note 9), at the very moment that her ethnic identity might be at political rest, given that the circumstances allow such comfortable relegation to the sphere of the implicit. Or both identities may be at a given time equally active, again, for reasons of felt oppression, real threat or even less crisis-ridden or crisis-tinted visions of a better life.

Habermas, who has famously criticized various theorists, M. Foucault among others, for failing to distinguish adequately between domination and power, himself fails to see that ethnic distinctiveness has had a specifically empowering role in people's resisting domination and that ethnic/national culture should not be taken (as liberal culturalism tends to do) as belonging to a rather private realm of existential choice of global cultural goods divorced from politics or to a folklore sense of culture. As Amilcar Cabral noted,

when Goebbels, the brain behind Nazi propaganda, heard culture being discussed, he brought out his revolver. That shows that the Nazis, who were and are the most tragic expression of imperialism and of its thirst for domination - even if they were all degenerates like Hitler, had a clear idea of the value of culture as a factor of resistance to foreign domination (Cabral, 2009, p. 1) (Note 10).

The value of culture had also been known to the colonial officials themselves: 'to take up arms to dominate a people is, above all, to take up arms to destroy, or at least to neutralize, to paralyze, its cultural life. For, with a strong indigenous cultural life, foreign domination cannot be sure of its perpetuation' (ibid). Some metonymies of this colonial practice? There are too many to account here; indicatively, one of the first things you come across when visiting Wales is local stories about the British colonial authorities' fight against Welsh language precisely to achieve the cultural homogeneity that would make it easier for them to rule over Wales. It would be unjust to describe the current, organized efforts on the part of the Welsh to revive their language as a 'nationalist' residue supposedly rendered obsolete in our postcolonial times. Likewise, it would be superficial to describe it as merely culturally 'ethnic' in the received sense, prior to extracting from the term 'ethnic' what goes beyond current connotations of folklore, heredity, and politically inoperative, ceremonial identity. For the revival of the Welsh language is not just a cultural phenomenon; it is replete with politically significant collective memory.

Hence, what has often motivated nationalism as the dream of the political liberty of a people and its voicing through a self-regulated state, has not just, or not always, been what E. Gellner pejoratively characterizes as arbitrary 'cultural shreds and patches' (Gellner, 2004, p. 56). Like in most overgeneralizations, here too, important nuances are missing when all cultural material used during national mobilizations is theorized as being of the arbitrary kind. One of Gellner's related aphorisms reads as follows: the cultures nationalism 'claims to defend and revive are often its own inventions, or are modified out of all recognition' (Gellner, 2004, p. 56). M. Hroch convincingly argues that Gellner's view that nations are a mere 'myth' is unacceptable (Hroch, 1998, p. 104), but, more specifically here, we may raise two objections to Gellner's assertion. First, Gellner uses 'often', and 'often' does not mean 'always'; in turn, this opens a whole series of concatenated effects about the under-theorization on his part of all the cases that do not conform to invention and myth. Second, even if the cultures that have, nationalistically, been defended had been invented, the people who benefited by escaping the raw or covert violence of conquest and occupation (e.g. of colonialism) were very real and not at all arbitrary. 


\section{The Nation and the Ethnos}

Ethnic patriotism/nationalism may not be as expendable or as disconnected from a principled political patriotism/nationalism as many thinkers believe today. But let me, now, explain in ascending order of importance what in the term 'ethnic' makes it more suitable than the term 'national' for a revisited patriotism and what in ethnicity goes beyond kinship or folklore. First, the term 'national' is often confoundedly used to refer to the nation-state [the political configuration consolidated in the $19^{\text {th }}$ century through print capitalism (Anderson, 2002)]. It is important at the definitional level to distinguish between the nation, the nation-state and ethnie (Smith, 2000; Armstrong, 2004) or race and ethnicity (Bartlett, 2001; Scruton, 2003). Second, national supremacy is not conceptually cognate with either the ethnic or the national as such. It can be reserved to denote a negative stance that grants either superiority or exclusive priority to one's group/country. Neither the ethnic nor the national affect leads automatically to the most common, negative use of nationalism (meaning chauvinism, jingoism and the like). The overuse of nationalism to denote everything from positive to negative collective attachment is mystifying and unproductive. Terms other than those related to the national can be utilized in order to deal with this predicament. Also, as nationalism refers to modern phenomena, other terms may be necessary in order to denote phenomena that are in a complex relation with, but perhaps pre-date, nationalism. Third, it can be shown, and this is what I shall attempt to do below, that the word 'ethnos', from which 'ethnic' derives, activates some important associations that are missing in the word 'nation'. These subvert or deconstruct the established association of the ethnos with biology and the nation with politics. For this reason, I believe that the translatability of nation into ethnos in Habermas [or the matching of ethnos to German Romanticist views of the nation and of demos to French views of the nation that P. Seriot (1997, p. 42ff) attempts (Note 11)] is not as unproblematic as it may seem at first sight.

This argument can be deployed with reference again to Habermas who traces the origin of the word 'nation' to the Romans and Natio, their goddess of birth and origin. This chimes with other broad and accurate, similar accounts of the nation (etymologically: from nascor = I am born). For instance, it chimes with Calhoun's remark that 'there is continuity between the Hebrew term translated as "nation" and the Roman usage. Both refer to a people organized as such on the basis of descent' (Calhoun, 2007, p. 1) (Note 12). Yet, though Habermas confines his account of the history of the word 'nation' to Roman antiquity, at another point in the same text (1996a, p. 23), he refers to ethnos as if it could be used interchangeably with the word 'nation'. The problem I see is not so much that his historical account does not go back enough but, more, that an assumption of easy translatability operates underneath Habermas's text.

Yet, I argue, ethnos is not so easily translatable into nation - not without an important surplus of meaning being left out. For, while the term 'nation' indeed described the bond of people on grounds of bloodline, as it was associated with the deity of birth and origin, the term 'ethnos' is far more complex. Ethnos derives from ethos (with Sanskrit etymological affinities) (Stamatakos, 2002, p. 303) and comprises meanings such as custom, mood, character, habit, abode and use. Though there is no conclusive evidence, the 'nos' of ethnos has sometimes been explained as deriving from the verb 'naīo' (to reside, dwell) or from 'naō' (to flow, run, stream) or from 'neō' (to swim or navigate). The connotations of all these possibilities, which are operative regardless of etymological accuracy, bring together the stability of the common abode (homeliness) (Note 13) with the mobility of flow and of a common navigation, the collective passage (homelessness) through a half-remembered, half-forgotten past and an unknown and uncertain future.

Hence, scholars of classics understand the ancient word 'ethnos' as meaning a group of people (or animals) cohabiting a specific land and having a specific way of living. Associations of bloodline remain in this meaning implicit and derivative, since the formative ideas are the group of people (collectivity), the connection with territoriality, the common cultural material and customs, and the course in space and time. True, the use of the term by ancient writers is not consistent and, as we will see below, the first, Herodotian attempt to define ethnos had not been particularly felicitous. 'As with other Greek concepts that have frustrated academic efforts to identify a consistent underlying signification independent of the meaning derived from contrasts with their cognitive complements, ethnos has defied modern analysis' (Cohen, 2003, p. 25). It is also true that 'some scholars have even charged Greek authors with "idiolectic" usage that effectively prevents rational determination of the word's objective meaning' (ibid). Yet, what is absolutely clear is that there is another term exclusively for kinship. A genos is 'a grouping in which membership is related to natal origins' (ibid); even when the genos is sometimes characterized as an ethnos for reasons of stark differentiation from the polis, it is nevertheless distinctively and exclusively related to bloodline - much unlike the ethnos, which has the association with ethos as we have just seen. Finally, unlike the Latin Natio (and the goddess of birth), it is noticeable that ethnos has no associations with a deified genetic origin. Thus, the word-for-word translatability of nation and ethnos is too facile and obscures some significant semantic differences that have not so far been explored. 
Before we proceed it is important here to confront two issues: groupism and mythos. The etymology of ethnos has enabling theoretical implications regarding the meaning of group as such. As there is nothing inherent in the etymology of ethnos that connects it automatically with genos, it is easier to avoid the danger of Brubaker's (1998, pp. 292-298) charge with groupism. An ontologically essentialist sense of group 'prevails in the study of ethnicity and nationalism' and attracts Brubaker's complaint that this leads those who 'write about ethnic groups and nations' to treating them as 'internally homogeneous and externally bounded collectivities' (1998, p. 292) (Note 14). The ethnic group sustained by ethos, abode, homeliness and homelessness can and should have always been (despite peoples' self-understandings) a porous structure or, perhaps, a kind of magma, where homeostatic equilibrium does not rule out accommodated or even assimilated heterogeneity that changes the texture of the ethnic material - much against purist assumptions. Of course, this is a strong claim that cannot be expounded within the limits of this article; and it is a possibility in need of empirical-historical support. It is stated, here, nevertheless, as a heuristic that clarifies the extent to which the notion of the ethnic redeemed here differs from essentialized or purist perennialist conceptions.

As is well-known, one of the debates in ethnicity and nation studies concerns the real or mythical nature of collectivities. Mythos in such a context takes on the modern sense of enabling, or, worse, expedient fiction. But mythos can have a more original and minimalist sense; that of an imaginative, collectively-held narrative (and varying) response to collectively raised questions about life and the world. In being a collectively-entertained response to questions about life and the world, mythos inescapably accompanies ethne in their navigation through time and varies accordingly. Nothing within this sense of myth brings it by definition closer to reality or fiction, truth or falsity, prior to examining and scrutinizing its contents. Interestingly, mythos accompanied ethnos in Greek antiquity from early on also in the first Greek attempt (to our knowledge) to answer the collective question about the imaginary unity beyond the confines of the tribe or the city. Hesiod's Catalogue of Women is the oldest, (8th century BC) partly extant, mythic account of Panhellenism (see, for instance, Rutherford, 2005) woven against a narrow tribalism of scattered gene and phyla. The presence of a genealogical-familial element in the myths (the children of Hellēn being the fathers of each phylon, etc) that Hesiod employed to explain a larger sense of belonging did not do justice to the richness of ethos/ethnos that we may extract from the etymology of the terms. It had rather been a historically specific way of answering the question about the ethnic bond.

And, for sure, even later, when Herodotus thematized ethnos (Note 15), he made it signify the constellation of consaguinity (omaimon), common religion (omothrēskon) and common language (omoglosson) (Herodotus, Book 8, Urania, 144. 2). In doing so, Herodotus defined it in a way that mystified the more minimalist premises of the term implicit in its etymological associations, and therefore raised the bloodline to an equal status with the cultural components that he had singled out (i.e., religion, language). Thus, Herodotus left out: a more general sense of common cultural life (e.g. one that includes memory, movement in time and narrativity); and the clearest manifestation of the collectively experienced, inescapable spatiotemporality of beings, i.e., home and homelessness. Nevertheless, even Herodotus's definition is not fully translatable into the Latin word 'nation', at least as we know it from the upshots of research up to now. For, the former combined cultural aspects with descent in an inextricable whole, whilst the latter gave, at least in most instances, exclusive priority to the bond of consanguinity. To realize why this might be significant, we need recall here that even Cicero, an otherwise very important thinker of Roman, Stoically influenced, cosmopolitanism, notoriously held the view that some nations are, supposedly due to genus, more servile and docile than the Romans (Note 16). Parenthetically, even if solely on such grounds, one can take issue with M. Viroli's emphasis only on the republican element in Ciceronian and more broadly Roman kind of patriotism (Viroli, 2003, p. 19 and p. 171).

Having stressed the enabling theoretical possibilities of the etymology of ethnos and the dismissal of those interpretations of affect that favor jus sanguinis, let us be cautious here. All this does not mean that only the biologistic conception of collective attachment leads to undesirable political consequences. The more broadly naturalist Aristotelian dichotomy of the slave and the free and his culturalist dichotomy of the Greek and the barbarian which, regrettably, triumphed over the egalitarian and cosmopolitan views of his opponents (e.g. Antiphon, Alcidamas, Philēmon) (Papastephanou, 2011) prove, once again, that political things can never be a simple matter of combating just one dangerous idea. Much against facile assumptions to the opposite, collective affect of all kinds cannot be sanitized and kept safe from any degeneration into pernicious modalities. Hence, this article is simply saying that a specific, positive meaning of patriotism can better be theorized by the term 'ethnic' rather than 'national' because the word ethnos comprises as yet unexplored counterfactual possibilities in stark contrast to a very common identification of the ethnic with kinship or, at most, with a de-politicized, folklore sense of culture. After all, if 'conceptual change is itself a species of political innovation' (Ball, Farr and Hanson, 1995, p. 2), at least in some cases, then, the deconstruction of sedimented meanings opens possibilities for fresh 
approaches to old theoretical questions, regardless of the feasibility of offering fresh solutions to old political problems.

As for the nation and the national, those can be reserved for modern politicizations of consanguinity or for modern specifications of the political relationship between modern self-understandings of peoples and the state. The ethnos, however, reflects more appropriately associations of: pre-modern cores of a politically active and demanding collective identity [just as Smith $(2000$, pp. 63 and $65 \mathrm{ff})$ has theorized with ethnie]; the redemptive politicization of collective homeliness (anti-colonialism, jus soli-based defence of land, insurrection and liberation efforts) that reached its peak in modernity but was grounded in a long-standing relation of peoples and dwelling; as well as meta-modern potentials for cultivating a rich interplay between homeliness and homelessness (Papastephanou, 2012).

To explain, the ethos of ethnos assists us in disentangling knots of collective affect beyond the traps of heredity that accompanied the historical course of the term 'nation' from Roman imperial antiquity to the present. Ethos as much more than custom (as it is usually translated) has enabling associations that are compatible with F. Fanon's challenge of the then theoretical tendency to combine the ancient customs (of various peoples) with those people's claims to authenticity. To Fanon, as T. Brennan puts it, custom in this sense locks culture up 'in a past sealed off from the vigorously altering effects of contemporary events' (1989, p. 17). The alternative task that Fanon assigns to custom is to "assimilate downwards by locating the "zone of occult instability where the people dwell"' (ibid). Dwelling here brings to mind the association of ethos with the abode, the home, the land that is defended through acts of resistance - a home that is a dynamic, porous, unstable and rich set of complex and often contradictory realities, always in interplay with the symbolic homelessness of the altering effects of temporality. As I understand him, Fanon's connection of ethos, plurality and resistance has, adapting Brennan's parlance here, been an attempt 'to recognize supple variations'. It does not 'fetishise the supposedly fixed identity of a metaphysical «people»' (Brennan, 1989, p. 17). Hence, in Fanon's statement below I find the best coupling of ethos and mythos (in the sense of thoughtful response to collective questions as mentioned above) that could underpin a revisiting and positive usage of ethnos and ethnic patriotism. 'A national culture is not a folklore nor an abstract populism discovering the people's «true nature»'. Instead, it is 'the whole body of efforts by a people in the sphere of thought' (Fanon, 1967, p. 188). In its relation to the previously stated connection of ethos, dwelling and lived instability with which events suffuse the everydayness of a people, Fanon's statement captures the ethnic affect that accommodates the best connotations of the ancient term 'ethnos' much more accurately than Herodotus's crude definition.

\section{Conclusions}

The persistence of the confounding employment of the ethnic and the national as interchangeable and indiscernible notions is as unproductive as their dichotomous theorization. Both tendencies have, so far and in one way or other, led to a de-politicization of the ethnic and an identification of the national with what pertains to the modern nation-state. The ethnic is taken to denote the common descent, the bloodline and the shared culture; the national is reserved for the civic. In this way, most of the toxic content of the term 'national' is now relegated to the ethnic. The latter is then dissociated from political claims, ceases to be an active identity and becomes harmless by acquiring a folklore character that disarms and contains the bond of consanguinity.

Without promoting an unsubstantiated empirical sanitization of the ethnic (or the civic for that matter), this article has claimed that the ethnic sentiment can become a complementary aspect, not a replacement of, constitutional attachment. To avoid sliding into their undesirable doubles both attachments require criticality and constant vigilance. A benign patriotism, then, cannot assume that it has solved its problems by confining itself to its constitutional potential. A challenge it faces is to comprise an ethnic aspect authorized by justice.

Rather than being undermined by the ethnos, this kind of full-fledged patriotism can be served by it, if the ethnos becomes understood in a way that differs from the received view on it. This new understanding is not arbitrarily decisionist; it can rely on the hidden possibilities of conceptual change that are implicit in its etymology. 'By uncovering and recovering lost meanings conceptual histories enable us to escape the politically stultifying confines of a parochial and increasingly dangerous present' (Ball, Farr and Hanson, 1995, p. 5). If the lost (or never quite held as yet) conception of ethnos that has been recovered/reconstructed here allows an interplay of collective homeliness and homelessness that keeps away metaphysical confines of unchosen membership, inescapability, bloodline, homogeneity, impermeability, groupism and so on, then, it makes belonging more critical and reflective while accommodating claims authorized by justice.

Within such conceptual re-direction, patriotism should comprise constitutional and ethnic aspects (which can both be political). Both aspects can be approached: from the affective perspective (love for the state and the 
community); from the ethico-political perspective of futurity (vision of an egalitarian, well-ordered state and a community that enjoys recognition, equality and fair treatment); from the historical perspective (avoidance of convenient selectivity regarding past entanglement with others and the debts that such entanglement may have created); and from the moral perspective (duties to fellow citizens or ethnic consociates, and moral responsibility for the community -be it a nation-state, region or ethnic community with a larger configuration or region- in the face of outside pressures of homogenization, exploitation, effacement or even ethnic cleansing).Thus, there is no drastic choice between constitutional/legalist-political/civic patriotism and ethnic patriotism, since all may deserve to be mobilized, depending on the context, the circumstances and the action that must be taken.

Patriotism can be meaningful today only as that kind of love and allegiance to a specific collectivity that defends it not against hospitability but against detrimental effects on its life world. Yet, for this qualification not to be an empty letter, patriotism should be the kind of love for the community/state that does not shy away in front of challenges to what it takes as 'detrimental'. Instead of protecting the 'home' from criticism, true patriotism drives criticism home and inspires struggle for self-betterment on grounds of a justice that harkens to others as much as to oneself. But, precisely because of this, true patriotism must also be understood as doubly self-restraining. It restrains the self within the collectivity (as much communitarianism assumes) but it should also restrain the collective self-regarding predatory aspirations against what lies outside the collectivity. It is also doubly enabling: it defends the freedom that any collectivity requires in order to flourish and achieve the criticality that any community is capable of; and it acknowledges and serves the legitimate claims of all that lies outside the community as well as the whole body of efforts by all peoples in the sphere of thought and action.

\section{References}

Anderson, B. (2002). Imagined Communities: Reflections on the origin and spread of nationalism. London: Verso.

Arendt, H. (1989). The Human Condition. Chicago: The University of Chicago Press.

Armstrong, J. A. (2004). Definitions, Periodization and Prospects for the Long Duree. Nations and Nationalism, 10(1-2), 9-18. http://dx.doi.org/10.1111/j.1354-5078.2004.00151.x

Ball, T., Farr, J., \& Hanson, R. (1995). Editors’ Introduction. In T. Ball, J. Farr, \& R. Hanson (Eds), Political Innovation and Conceptual Change. Cambridge: Cambridge University Press.

Bartlett, R. (2001). Medieval and Modern Concepts of Race and Ethnicity. Journal of medieval and Early Modern Studies, 31(1), 39-56. http://dx.doi.org/10.1215/10829636-31-1-39

Ben-Porath, S. (2006). Citizenship Under Fire: Democratic Education in Times of Conflict. Princeton and Oxford: Princeton University Press. PMCid:1395448

Brennan, T. (1989). Cosmopolitans and Celebrities. Race and Class, 31(1), 1-19. http://dx.doi.org/10.1177/030639688903100102

Brubaker, R. (1998). Myths and Misconceptions in the Study of Nationalism. In J. A. Hall (Ed.), The State of the Nation (pp. 272-306). Cambridge: Cambridge University Press. http://dx.doi.org/10.1017/CBO9780511897559.013

Cabral, A. (2009). National Liberation and Culture. The Journal of Pan African Studies, 3(5). Retrieved December 8, 2010, from http://www.jpanafrican.com/edocs/e-DocCabral3.5.pdf

Calhoun, C. (2007). Nations Matter: Culture, History, and the Cosmopolitan Dream. London and N. York: Routledge.

Cohen, E. (2003). The Athenian Nation. New Jersey: Princeton University Press.

Fanon, F. (1967). The Wretched of the Earth. Harmondsworth: Penguin.

Gellner, G. (2004). Nations and Nationalism. Oxford: Blackwell. PMid:15305914

Habermas, J. (1996a). Citizenship and National Identity. In V. B. Steenbergen (Ed.), The Condition of Citizenship. London: Sage.

Habermas, J. (1996b). Die Einbeziehung des Anderen: Studien zur Politischen Theorie. Frankfurt a. M: Suhrkamp. PMid:9156686

Hall, J. A. (1998). Introduction. In J. A. Hall (Ed.). The State of the Nation (pp. 1-20). Cambridge: Cambridge University Press. http://dx.doi.org/10.1017/CBO9780511897559.001

Held, D. (2003). Cosmopolitanism: Globalisation Tamed? Review of International Studies, 29, 465-480. http://dx.doi.org/10.1017/S0260210503004650 
Hroch, M. (1998). Real and Constructed: the nature of the nation. In J. A. Hall (Ed.), The State of the Nation (pp. 91-106). Cambridge: Cambridge University Press. http://dx.doi.org/10.1017/CBO9780511897559.004

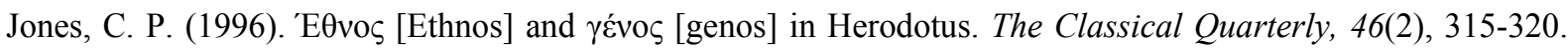
http://dx.doi.org/10.1093/cq/46.2.315

Kaldor, M. (2004). Nationalism and Globalization. Nations and Nationalization, 10(1-2), 161-177. http://dx.doi.org/10.1111/j.1354-5078.2004.00161.x

Kant, I. (1992). Political Writings. Cambridge: Cambridge University Press.

Kleingeld, P. (2000). Kantian Patriotism. Philosophy and Public Affairs, 29(4), 313-341. http://dx.doi.org/10.1111/j.1088-4963.2000.00313.x

Knight A. K., \& Harnish, J. (2006). Contemporary Discourses of Citizenship. Review of Educational Research, 76(4), 653-690. http://dx.doi.org/10.3102/00346543076004653

Linklater, A. (2002). The Problem of Harm in World Politics: Implications for the Sociology of States-Systems. International Affairs, 78(2), 319-338. http://dx.doi.org/10.1111/1468-2346.00253

MacIntyre, A. (2003). Is Patriotism a Virtue? In D. Matravers, \& J. Pike (Eds.), Debates in Contemporary Political Philosophy (pp. 286-300). London: Routledge and Open University.

Miller, D. (2003). In Defence of Nationality. In D. Matravers, \& J. Pike (Eds.), Debates in Contemporary Political Philosophy (pp. 301-318). London: Routledge and Open University.

Nairn, T. (1998). The Curse of Rurality: Limits of modernization theory. In J. A. Hall (Ed.), The State of the Nation (pp. 107-134). Cambridge: Cambridge University Press. http://dx.doi.org/10.1017/CBO9780511897559.005

Nederveen P. J. (1996). Varieties of Ethnic Politics and Ethnicity Discourse. In Wilmsen, E., \& McAllister, P. (Eds.), The Politics of Difference: ethnic premises in a world of power (pp. 25-44). Chicago: University of Chicago Press.

Nielsen, K. (2003). Toward a Liberal Socialist Cosmopolitan Nationalism. International Journal of Philosophical Studies, 11(4), 437-463. http://dx.doi.org/10.1080/0967255032000136470

O' Leary, B. (1998). Ernest Gellner's Diagnoses of Nationalism: A critical overview, or, what is living and what is dead in Ernest Gellner's philosophy of nationalism? In J. A. Hall (Ed.), The State of the Nation (pp. 40-88). Cambridge: Cambridge University Press. http://dx.doi.org/10.1017/CBO9780511897559.003

Papastephanou, M. (2011). The Philosopher, the Sophist, the Undercurrent and Alain Badiou. Speculations, 1(2), 275-311.

Papastephanou, M. (2012). Thinking Differently About Cosmopolitanism: Theory, Eccentricity and a Globalized World. Boulder: Paradigm Publishers.

Papastephanou, M. Inward and Outward Patriotism (forthcoming).

Rutherford, I. (2005). Mestra at Athens: Hesiod fr. 43 and the Poetics of Panhellenism. In R. Hunter (Ed.), The Hesiodic Catalogue of Women: constructions and reconstructions (pp. 99-117). Cambridge: Cambridge University Press.

Sériot, P. (1997). Ethnos et demos: la construction discursive de l' identité collective. Langage et Société, n 79Q, 39-51. http://www.persee.fr/web/revues/home/prescript/article/lsoc_0181-4095_1997_num_79_1_2772.

Scruton, R. (2003). In Defence of the Nation. In D. Matravers, \& J. Pike (Eds.), Debates in Contemporary Political Philosophy (pp. 271-285). London: Routledge and Open University.

Smith, A. D. (2000). The Nation in History. Cambridge: Polity Press.

Squatriti, P. (2007). Introduction. In Squatriti (Trans), The Complete Works of Liudprand of Cremona (pp. 3-40). Washington: The Catholic University of America Press.

Stamatakos, I. (2002). Lexikon tis Archaias Ellinikis Glossas. Dictionary of Ancient Greek Language. Athens: Vivliopromitheytiki.

Stanton, G. H. (1998). The Eight Stages of Genocide. Retrieved October 25, 2012, from http://www.learning4u2.com/HAL/Independent\%20study\%20pages/Anne_Frank/Genocide\%20Watch.pdf

Taylor, C. (1996). Why Democracy Needs Patriotism. In Cohen, J., \& Nussbaum, M. (Eds.), For Love of Country: Debating the Limits of Patriotism. Boston: Beacon. 
Taylor, C. (1998). Nationalism and Modernity. In J. A. Hall (Ed.), The State of the Nation (pp. 191-218). Cambridge: Cambridge University Press. http://dx.doi.org/10.1017/CBO9780511897559.009

Viroli, M. (2003). For Love of Country: an essay on patriotism and nationalism. Oxford: Oxford University Press.

\section{Notes}

Note 1. 'For precisely the same reasons that a family whose members all came to regard membership in that family as governed only by reciprocal self-interest would no longer be a family in the traditional sense, so a nation whose members took up a similar attitude would no longer be a nation' (MacIntyre, 2003, p. 298).

Note 2. 'An analogy with the family makes this clear. A family does not exist as such unless its members have certain feelings towards one another, yet obligations within a family are not governed by sentiment' (Miller, 2003, pp. 314-5).

Note 3. Civic patriotism is love for common political liberty and the institutions that support it. This kind of patriotism is inherently political (Taylor, 1998, pp. 201-2); it does not depend on ethnic or national identities (Kleingeld, 2000, p. 317).

Note 4 . We must not forget that these two are not identical, but here there is no space for exploring the intricacies of such a distinction.

Note 5. By 'ontologization' I mean here the elevation of the specific modern conceptual content of the terms to the status of the only meaning that the terms may legitimately acquire, i.e. a kind of conceptual essentialism and onto-theology that arrests time by raising modern time to the history proper of ethnos and nation. A similar ontologization lurks in the kind of sacralisation of common English usage of ethnic and national that treats any attempt to redefinitions as odd to say the least. Indeed, in English, that someone is half Spanish and half French refers to her ethnicity qua having one Spanish and one French parent; as I have been pointed out by a reviewer of another paper (to whom I am indebted) it is much rarer to talk about the nationality in halves and quarters in English. But, that ethnicity is so associated with descent rather than politics in ordinary English usage is, to me, no compelling argument for refraining from revisiting the term 'ethnic', unless one ontologizes and sacralizes that usage. The question is rather whether there is conceptual ground and theoretical import in the attempt to revisit the term, and this is what I shall show in the rest of this article.

Note 6 . The use of patriotism and nationalism interchangeably here for reasons of avoiding needless intricacy as a differentiation of that sort would go beyond the aims of this article should not make us lose sight of the fact that they are also distinct, both historically and conceptually (Papastephanou, 2012).

Note 7. Taylor concurs with him on the apolitical character of pre-modern nations. Thus, the illustration related to Liudprand that I discuss below contravenes also Taylor's assumption that irredentist claims (e.g. of the Algerians) could have only arisen in modernity (1998, pp. 204-5).

Note 8. Relatio de legatione Constantinopolitana ad Nicephorum Phocam. Online translation at UCdavis.edu. Liutprand of Cremona: Report of his Mission to Constantinople. http://medieval.ucdavis.edu/20A/Luitprand.html Downloaded 10/12/2010.See also Bartlett's (2001) use of this example. On how Liudprand deployed his ethnic sensitivity by means of constructive images of 'us' against destructive images of 'they' (the tarnished images of the Byzantine conquerors), see P. Squatriti (2007, p. 34). For a more general account of 'we' and 'they' constructions and an interesting approach to their political function in classifications that may eventually lead event genocide, see Gregory H. Stanton (1998). I thank the anonymous reviewer of the journal for drawing my attention to it.

Note 9. A disclaimer here: I do not imply that people are mobilized only when they are directly, through their own identity, involved in relations of domination.

Note 10. As becomes obvious from reading his text as a whole, by 'culture' Cabral meant the distinctively national character of culture.

Note 11. Seriot connects 'une conception de la nation comme ethnos' (p. 48) with 'la définition romantique allemande [qui] est un jus sanguinis (le droit du sang)' (p. 43); by contrast, a contrast reminiscent of the standard distinction between ethnic and civic patriotism, in his conceptualization, 'la definition jacobine française de la nation [qui] est un jus soli (le droit du sol)' (ibid).

Note 12. However, even this usage had not been apolitical since, for the Romans, it grounded their distinction between their polity and the non-Roman subjects of the Empire (Calhoun, 2007, p. 1). 
Note 13. In an interesting parallel, one of the Arabic words for nation is watan which derives from 'watana, to dwell, and identifies a people purely in terms of its dwelling place' (Scruton, 2003, p. 274).

Note 14. He also seems to object to seeing ethnic groups as 'real entities', but, as there is a huge issue about what counts as philosophically real, an issue that cannot be dealt with here, we may leave this objection to one side. We can do so because, in any case, some implicit assumptions about what I believe should count as real will surface in the specific meaning that I give to myth.

Note 15. On conflations of ethnos with genos in Herodotus, see Jones (1996).

Note 16. M. Tullius Cicero, Orationes: Pro Milone, Pro Marcello, Pro Ligario, Pro regeDeiotaro, Philippicae I-XIV (ed. Albert Clark, Oxford 1918.) Online at Tufts.edu 